〔J. Appl. Glycosci., Vol. 46, No.4, p. 423-429 (1999)〕

\title{
Purification and Characterization of a Novel Phosphorylase, Kojibiose Phosphorylase, from Thermoanaerobium brockii
}

\author{
Hiroto Chaen,* Takuo Yamamoto, Tomoyuki Nishimoto, \\ Tetsuya Nakada, Shigeharu Fukuda, Toshiyuki Sugimoto, \\ Masashi Kurimoto and Yoshio Tsujisaka \\ Hayashibara Biochemical Laboratories, Inc. (7-7, Amase-minami machi, \\ Okayama 700-0834, Japan)
}

\begin{abstract}
The thermophilic anaerobe Thermoanaerobium brockii ATCC 35047 produces a novel phosphorylase, kojibiose phosphorylase, which catalyzes the reversible phosphorolysis of kojibiose to form $\beta$-glucose 1-phosphate and D-glucose. The enzyme was purified from a cell-free extract to an electrophoretically homogeneous state by successive column chromatography on DEAE-Toyopearl 650S, CM-Toyopeärl 650S, Hydroxyapatite, Ultrogel AcA44, Mono Q, and Butyl-Toyopearl $650 \mathrm{M}$. The enzyme had a molecular weight of 83,000 by SDS-polyacrylamide gel electrophoresis and a $\mathrm{p} I$ of 4.3 to 4.4 by gel isoelectrofocusing. The enzyme showed the highest activity at pH 5.5 and $65^{\circ} \mathrm{C}$, and was stable from pH 5.5 to 9.7 and up to $65^{\circ} \mathrm{C}$. The enzyme activity was inhibited by $\mathrm{Hg}^{2+}$ and $\mathrm{Pb}^{2+}$. The $K_{\mathrm{m}}$ values for kojibiose, $\mathrm{Pi}$, glucose, and $\beta$-glucose 1 -phosphate were $0.77,0.85,3.52$, and $0.77 \mathrm{mM}$, respectively.
\end{abstract}

Kojibiose (2-O- $\alpha$-D-glucopyranosyl $\alpha$-D-glucopyranose) is a disaccharide that has been isolated from koji-extract, ${ }^{1)}$ beer, ${ }^{2)}$ honey, ${ }^{3)}$ and starch hydrol. ${ }^{4)}$ In general, this disaccharide is prepared from a partial acetolyzate of Leuconostoc mesenteroides NRRL B-1299 dextran.5) Chiba et al. ${ }^{6}$ ) reported the enzymatic synthesis of kojibiose and nigerose (3- $O-\alpha$-D-glucopyranosyl $\alpha$-D-glucopyranose) from starch by the transglucosylation of buckwheat $\alpha$-glucosidase. As reported in our previous paper, ${ }^{7)}$ we found that a cell-free extract from a thermophilic anaerobe, Thermoanaerobium brockii ATCC 35047, showed the activity to produce a trisaccharide, selaginose (2-O- $\alpha$-D-glucopyranosyl $\alpha$-D-glucopyranosyl $\alpha$-D-glucopyranoside), from trehalose. In addition, it was suggested that selaginose was produced by two reactions which catalyzed by two thermostable phosphorylases, trehalose phosphorylase (TPase) and a novel phosphorylase. It was considered that the

\footnotetext{
* Corresponding author.

Abbreviations: KPase, kojibiose phosphorylase; TP. ase, trehalose phosphorylase; $\beta$-G $1 \mathrm{P}, \beta$-D-glucose 1 phosphate; $\mathrm{Pi}$, inorganic phosphate.
}

novel phosphorylase catalyzed the reversible phosphorolysis of kojibiose as follows:

$$
\beta \text {-G1P + D-glucose } \leftrightarrow \text { kojibiose }+\mathrm{Pi}
$$

We proposed that the novel enzyme was kojibiose phosphorylase (KPase). At present, five enzymes, sucrose phosphorylase (EC 2.4.1.7), maltose phosphorylase (EC 2.4.1.8), cellobiose phosphorylase (EC 2.4.1.20), laminaribiose phosphorylase (EC 2.4.1.31) and trehalose phosphorylase (EC 2.4.1.64), are classified into disaccharide phosphorylase. ${ }^{8-12)}$ However, no report has been observed on the phosphorylase that acts on the $\alpha-1,2$ glucosidic linkage.

In this paper, we describe the purification and properties of a novel enzyme, KPase, from a thermophilic anaerobe, Thermoanaerobium brockii ATCC 35047.

\section{MATERIALS AND METHODS}

Materials. CM-Toyopearl 650S was purchased from Tosoh Co., Ltd. Hydroxyapatite was purchased from Wako Pure Chemical Industries. Mono $\mathrm{Q}$ was purchased from Pharmacia Biotech. 
Microorganism and cultivation. Thermoanaerobium brockii ATCC 35047 was used in this study. Medium and conditions for cultivation were described in our previous paper. ${ }^{7)}$

Enzyme assay.

Phosphorolytic activity. The reaction mixture for kojibiose phosphorolysis contained $0.1 \%$ kojibiose, McIlvaine buffer ( $\mathrm{pH} 5.5 \mathrm{Pi}$ concentration; $102 \mathrm{mM}$ ), and the enzyme in a total volume of $2.2 \mathrm{~mL}$. After incubation at $60^{\circ} \mathrm{C}$ for $30 \mathrm{~min}$, the reaction was stopped by boiling for $10 \mathrm{~min}$. Released glucose was measured by the glucose oxidase-peroxidase method. ${ }^{13)}$ One unit of enzyme activity was defined as the amount of the enzyme that liberates glucose at $1 \mu \mathrm{mol} /$ min under the above-mentioned conditions.

Synthetic activity. The reaction mixture for kojibiose synthesis contained $0.1 \%$ glucose, $0.1 \% \beta$-glucose 1 -phosphate, $50 \mathrm{~mm}$ acetate buffer ( $\mathrm{pH} 5.5$ ), and the enzyme in a total volume of $1.1 \mathrm{~mL}$. After incubation at $60^{\circ} \mathrm{C}$ for various times, each reaction was stopped by boiling for $10 \mathrm{~min}$. Released $\mathrm{Pi}$ was measured by the method of Fiske and Subbarow. ${ }^{14)}$

Purification of KPase.

Step 1. Extraction. The cell-free extract of Thermoanaerobium brockii ATCC 35047 was obtained as described in our accompanying paper (H. Chaen, accompanying paper).

Step 2. Ammonium sulfate precipitation. Ammonium sulfate precipitation was done as described in our accompanying paper $(\mathrm{H}$. Chaen, accompanying paper).

Step 3. DEAE-Toyopearl 650S column chromatography. Chromatography on a DEAEToyopearl 650S column was done as described in our accompanying paper $(\mathrm{H}$. Chaen, accompanying paper). The active fractions of KPase were collected and dialyzed against 10 $\mathrm{mM}$ citrate- $\mathrm{Na}_{2} \mathrm{HPO}_{4}$ buffer (pH 5.2).

Step 4. CM-Toyopearl $650 S$ column chromatography. The dialyzate was put on a column $(1.6 \times 22 \mathrm{~cm})$ of CM-Toyopearl $650 \mathrm{~S}$ equilibrated with $10 \mathrm{mM}$ citrate- $\mathrm{Na}_{2} \mathrm{HPO}_{4}$ buffer ( $\mathrm{pH}$ 5.2). The enzyme was eluted with a linear gradient from 0 to $0.4 \mathrm{M} \mathrm{NaCl}$ in the same buffer. The active fractions were combined and dialyzed against $10 \mathrm{~mm}$ sodium phosphate buffer ( $\mathrm{pH} 7.0)$.
Step 5. Hydroxyapatite column chromatography. The dialyzate was put on a column $(1.6 \times$ $22 \mathrm{~cm}$ ) of Hydroxyapatite equilibrated with 10 mM sodium phosphate buffer (pH 7.0). The enzyme was eluted with a linear gradient from 0.01 to $0.2 \mathrm{M}$ sodium phosphate. The active fractions were combined and concentrated to a volume of $3 \mathrm{~mL}$ on an UF module, Ultracent-30 (Tosoh Co.).

Step 6. Ultrogel AcA44 column chromatography. The concentrated enzyme solution was put on a column $(2.0 \times 97 \mathrm{~cm})$ of Ultrogel AcA44 equilibrated with $10 \mathrm{mM}$ sodium phosphate buffer ( $\mathrm{pH} 7.0$ ) containing $0.2 \mathrm{M} \mathrm{NaCl}$ and eluted with the same buffer. The active fractions were combined and dialyzed against $10 \mathrm{mM}$ sodium phosphate buffer ( $\mathrm{pH} 7.0$ ) containing $0.1 \mathrm{M} \mathrm{NaCl}$.

Step 7. Mono $Q$ column chromatography. The dialyzate was put on a column $(0.5 \times 5 \mathrm{~cm})$ of Mono $\mathrm{Q}$ equilibrated with $10 \mathrm{mM}$ sodium phosphate buffer ( $\mathrm{pH} 7.0$ ) containing $0.1 \mathrm{M}$ $\mathrm{NaCl}$. The enzyme was eluted with a linear gradient from 0.1 to $0.4 \mathrm{M} \mathrm{NaCl}$ in the same buffer. The active fractions were combined and brought to a $1.2-\mathrm{M}$ concentration of $\left(\mathrm{NH}_{4}\right)_{2} \mathrm{SO}_{4}$ by adding solid $\left(\mathrm{NH}_{4}\right)_{2} \mathrm{SO}_{4}$.

Step 8. Butyl-Toyopearl $650 \mathrm{M}$ column chromatography. The enzyme solution was put on a column $(1.0 \times 11 \mathrm{~cm})$ of Butyl-Toyopearl $650 \mathrm{M}$ equilibrated with $10 \mathrm{~mm}$ sodium phosphate buffer ( $\mathrm{pH} 7.0)$ containing $1.2 \mathrm{M}\left(\mathrm{NH}_{4}\right)_{2} \mathrm{SO}_{4}$. It was eluted with a linear gradient from 1.2 to $0 \mathrm{M}\left(\mathrm{NH}_{4}\right)_{2} \mathrm{SO}_{4}$ in the same buffer. The active fractions were pooled as the purified enzyme preparation.

Substrate specificity. Substrate specificities of the enzyme for phosphorolysis were tested using various disaccharides. Enzyme activity was measured by the glucose liberated. The substrate concentration was $0.1 \%$ in $0.1 \mathrm{M}$ sodium arsenate-citrate buffer ( $\mathrm{pH} 5.5$ ).

Acceptor specificity. Acceptor specificities of the enzyme were tested according to the synthesis, substituting various mono-, di-, and oligosaccharides as acceptors for glucose. The reaction mixture was analyzed by thin-layer chromatography (TLC) and gas-liquid chromatography (GLC) . 
HPLC. HPLC analysis of sugar was carried out using a CCPM pump, a RI-8012 differential refractive index monitor, and SC-8010 data processor (all from Tosoh Co.) under the following conditions: column, YMC-pak ODS AQ-303 $(250 \times 4.6 \mathrm{~mm}$, YMC Co.); column temperature, $35^{\circ} \mathrm{C}$; mobile phase, water; and flow rate, $0.4 \mathrm{~mL} / \mathrm{min}$.

Unless otherwise described above, all materials and methods used for this study were the same as those described in our accompanying paper (H. Chaen, accompanying paper).

\section{RESULTS}

\section{Purification of KPase.}

Table 1 shows a summary of the purification of KPase from T. brockii ATCC 35047. The enzyme was purified about 5500-fold with a $10.6 \%$ yield from the cell-free extract. The specific activity of the purified enzyme preparation obtained by Butyl-Toyopearl $650 \mathrm{M}$ column chromatography was $71.4 \mathrm{U} / \mathrm{mg}$ protein. The purified enzyme preparation showed no TPase activity (less than $0.05 \%$ ) and gave a single band by PAGE.

\section{Physical properties of KPase.}

The molecular weight of the enzyme was estimated to be 83,000 by SDS-PAGE (Fig. 1A). The molecular weight of the native enzyme was estimated to be 500,000 by gel filtlation on a TSKgel G4000SW column (Fig. 1B). The $\mathrm{p} I$ was from 4.3 to 4.4 by gel isoelectrofocusing. The $\mathrm{N}$-terminal amino acid sequence up to the 15 th residue was determined to be: $\mathrm{NH}_{2}$-Met-
(A)

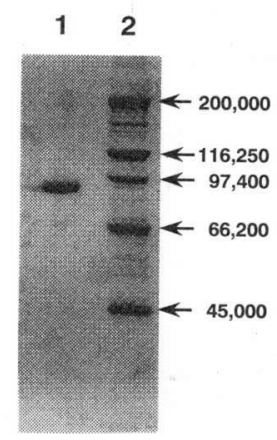

(B)

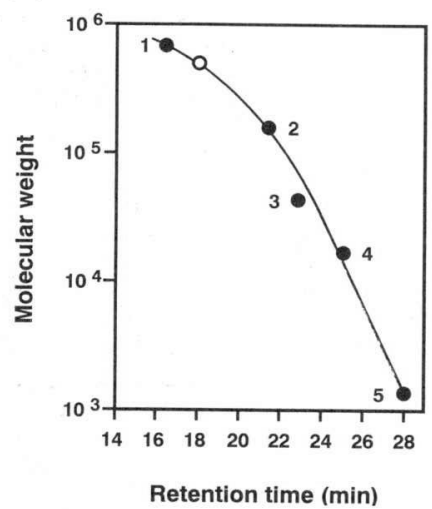

Fig. 1. Homogeneity of purified KPase and molecular weight measurement.

(A) SDS-PAGE. Lane 1, purified KPase; lane 2, standard protein mixture containing myosin (Mw 200,000), $\beta$-galactosidase $(116,250)$, phosphorylase $(97,000)$, serum albumin $(66,200)$, and ovalbumin $(45,000)$. (B) Gel filtration (TSKgel G4000SW). O, purified KPase; $-1-5$, respectively, correspond to thyroglobulin $(\mathrm{Mw} 670,000)$, gamma globulin $(158,000)$, ovalbumin $(44,000)$, myoglobin $(17,000)$, and vitamin B-12 (1350).

Val-Lys-His-Met-Phe-Leu-Glu-Asp-Val-AsnAsn-Leu-Ile-Ser.

\section{Enzymatic properties of KPase.}

The effects of $\mathrm{pH}$ and temperature on the phosphorolytic activity and stability are shown in Fig. $2 \mathrm{~A}$ and $\mathrm{B}$, respectively. The optimum $\mathrm{pH}$ was 5.5 , and the enzyme was stable from $\mathrm{pH}$ 5.5 to 9.7 . The optimum $\mathrm{pH}$ in the synthetic direction was the same value of phosphorolysis, 5.5 (data not shown). The optimum temperature was $65^{\circ} \mathrm{C}$, and the enzyme was stable up to

Table 1. Summary of purification procedure of KPase from Thermoanaerobium brockii ATCC 35047.

\begin{tabular}{lccccc}
\hline \multicolumn{1}{c}{ Step } & $\begin{array}{c}\text { Total protein } \\
(\mathrm{mg})\end{array}$ & $\begin{array}{c}\text { KPase activity } \\
(\mathrm{U})\end{array}$ & $\begin{array}{c}\text { Specific } \\
\text { activity } \\
(\mathrm{U} / \mathrm{mg})\end{array}$ & $\begin{array}{c}\text { Purification } \\
\text { factor } \\
(\text {-fold })\end{array}$ & $\begin{array}{c}\text { Recovery } \\
(\%)\end{array}$ \\
\hline Extraction & 21400 & 270 & 0.013 & 1 & 100 \\
$\left(\mathrm{NH}_{4}\right)_{2} \mathrm{SO}_{4}$ precipitation & 18500 & 251 & 0.014 & 1.1 & 93.0 \\
DEAE-Toyopearl 650S & 349 & 212 & 0.608 & 46.8 & 78.5 \\
CM-Toyopearl 650S & 34.0 & 136 & 4.00 & 308 & 50.4 \\
Hydroxyapatite & 8.44 & 130 & 15.4 & 1190 & 48.1 \\
Ultrogel AcA44 & 2.58 & 109 & 42.2 & 3250 & 40.4 \\
Mono Q & 1.50 & 78.6 & 52.4 & 4030 & 29.1 \\
Butyl-Toyopearl 650 M & 0.401 & 28.6 & 71.3 & 5490 & 10.6 \\
\hline
\end{tabular}


(A)

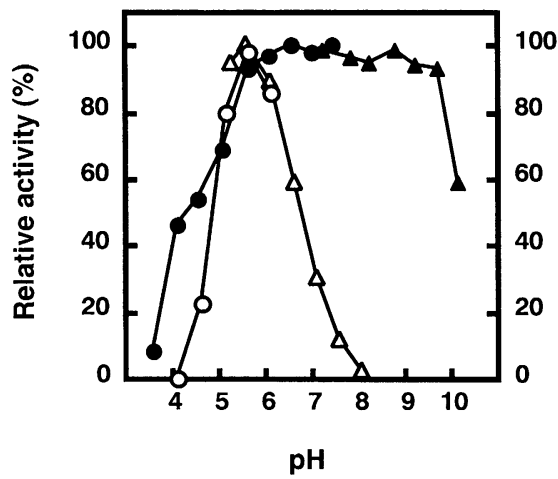

(B)

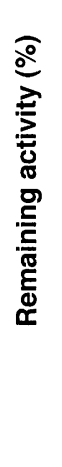

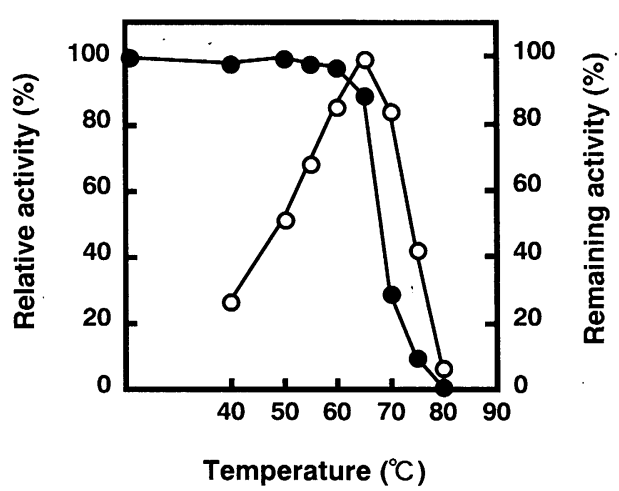

Fig. 2. Effects of $\mathrm{pH}$ and temperature on the activity and stability of KPase.

(A) For the $\mathrm{pH}$ test, $0.2 \mathrm{~m}$ sodium arsenate-citrate buffer $(\mathrm{pH} 4.0-6.0$ ) and $0.2 \mathrm{M}$ sodium arsenate$\mathrm{HCl}$ buffer ( $\mathrm{pH}$ 5.0-8.0) were used. The enzyme activities at various $\mathrm{pHs}$ were assayed. Citrate$\mathrm{Na}_{2} \mathrm{HPO}_{4}$ buffer ( $\mathrm{pH}$ 3.5-7.5) and glycine- $\mathrm{NaOH}$ buffer ( $\mathrm{pH} 7.5-10.5$ ) were used to examine $\mathrm{pH}$ stability. The enzyme was incubated for $24 \mathrm{~h}$ at $4^{\circ} \mathrm{C}$, and the remaining activities were assayed at $\mathrm{pH}$ 5.5. $\bigcirc$, activity; $-\mathrm{pH}$ stability. (B) The enzyme activities were assayed at various temperatures. To examine thermal stability, the enzyme was incubated at various temperatures $\left(40-80^{\circ} \mathrm{C}\right)$ for $60 \mathrm{~min}$ in Mcllvaine buffer ( $\mathrm{pH}$ 5.5) and cooled immediately. The remaining activities were assayed at $65^{\circ} \mathrm{C}$. $\bigcirc$, activity; - , thermal stability.

$65^{\circ} \mathrm{C}$. The enzyme activity was strongly inhibited by $\mathrm{Hg}^{2+}$ and moderately by $\mathrm{Pb}^{2+}$ (data not shown).

\section{Substrate specificity.}

In order to investigate the substrate specificity of KPase for phosphorolytic direction, various disaccharides were examined as substrates. KPase was specifically active on kojibiose and inactive on other disaccharides such as sophorose, trehalose, neotrehalose, nigerose, laminaribiose, maltose, cellobiose, isomaltose, gentiobiose, sucrose, and lactose (Table 2):

Substrate specificity for synthetic direction (acceptor specificity) was examined using $\beta$ G1P as a glucosyl donor and various mono-, di-, and oligosaccharides as acceptors. As shown in Table 3, D-glucose, L-sorbose, methyl- $\alpha$-Dglucose, and methyl- $\beta$-D-glucose were effective acceptors among various monosaccharide. Dand L-Xylose also acted as acceptors, but their transfer ratios were less than 25\%. Furthermore, trehalose, neotrehalose, kojibiose, nigerose, maltose, isomaltose, laminaribiose, cellobiose, gentiobiose, maltitol, sucrose, palatinose, maltulose, turanose, and maltooligosaccharides
Table 2. Substrate specificity of KPase for phosphorolytic direction.

\begin{tabular}{lcc}
\hline Substrate & Linkage & $\begin{array}{c}\text { Relative activity } \\
(\%)\end{array}$ \\
\hline Kojibiose & $\alpha-1,2$ & 100 \\
Sophorose & $\beta-1,2$ & 0 \\
Trehalose & $\alpha \cdot \alpha-1,1$ & 0 \\
Neotrehalose & $\alpha, \beta-1,1$ & 0 \\
Nigerose & $\alpha-1,3$ & 0 \\
Laminaribiose & $\beta-1,3$ & 0 \\
Maltose & $\alpha-1,4$ & 0 \\
Cellobiose & $\beta-1,4$ & 0 \\
Isomaltose & $\alpha-1,6$ & 0 \\
Gentiobiose & $\beta-1,6$ & 0 \\
Sucrose & $\beta-2,1(\mathrm{Fru}-\mathrm{Glc})$ & 0 \\
Lactose & $\beta-1,4(\mathrm{Gal}-\mathrm{Glc})$ & 0 \\
Selaginose & $\alpha-1,2 ; \alpha, \alpha-1,1$ & 36.5 \\
\hline
\end{tabular}

$0.1 \mathrm{M}$ Sodium arsenate-citrate buffer $\mathrm{pH} 5.5$ was used. The enzyme was incubated in the presence of various substrates for $30 \mathrm{~min}$ at $60^{\circ} \mathrm{C}$, and the glucose released was measured.

were also effective acceptors.

Kinetic parameters.

Double reciprocal plots on initial velocities versus substrate concentration for kojibiose, 
Table 3. Acceptor specificity of KPase.

\begin{tabular}{lc}
\hline \multicolumn{1}{c}{ Acceptor } & Product \\
\hline D-Glucose & +++ \\
D-Xylose & + \\
L-Xylose & + \\
D-Galactose & - \\
D-Fructose & - \\
D-Mannose & - \\
D-Arabinose & - \\
L-Arabinose & - \\
D-Fucose & - \\
L-Fucose & - \\
L-Sorbose & +++ \\
D-Ribose & - \\
L-Rhamnose & - \\
Metyl- $\alpha$-D-glucopyranoside & +++ \\
Metyl- $\beta$-D-glucopyranoside & +++ \\
2-Deoxy-D-glucose & - \\
$N$-Acetyl-D-glucosamine & - \\
D-Glucosamine & - \\
Sorbitol & - \\
Trehalose & ++ \\
Neotrehalose & ++ \\
Kojibiose & ++ \\
Nigerose & ++ \\
Maltose & ++ \\
Isomaltose & ++ \\
Laminaribiose & ++ \\
Cellobiose & ++ \\
Gentiobiose & ++ \\
Maltitol & ++ \\
Sucrose & ++ \\
Palatinose & ++ \\
Maltulose & ++ \\
Turanose & ++ \\
Lactose & ++ \\
Melibiose & ++ \\
Lactulose & ++ \\
Maltotriose & ++ \\
Maltotetraose & \\
Maltopentaose & \\
\hline &
\end{tabular}

The transfer ratio to acceptor was detected by GLC. ,$+++ 50 \%<$ transfer ratio;,$++ 25 \%<$ transfer ratio $\leq 50 \% ;+, 0 \%<$ transfer ratio $\leq 25 \% ;-$, no detected transfer product to acceptor. ${ }^{a}$ Detected by TLC.

$\mathrm{Pi}, \beta$-G1P, and D-glucose showed a series of straight lines (data not shown). The apparent $K_{\mathrm{m}}$ values and $k_{\text {cat }}$ s for substrates calculated from these plots are shown in Table 4 . The $K_{\mathrm{m}}$ values for kojibiose, $\mathrm{Pi}, \beta$-G1P, and D-glucose were $0.77,0.85,3.52$, and $0.77 \mathrm{mM}$, respectively.
Table 4. Kinetic parameters of KPase.

\begin{tabular}{lcc}
\hline Substrate & $\begin{array}{c}K_{\mathrm{m}} \\
(\mathrm{mM})\end{array}$ & $\begin{array}{c}k_{\text {cat }} \\
\left(\mathrm{s}^{-1}\right)\end{array}$ \\
\hline Kojibiose & 0.77 & $1.7 \times 10^{2}$ \\
$\mathrm{Pi}$ & 0.85 & $1.7 \times 10^{2}$ \\
Glucose & 3.52 & $6.5 \times 10^{2}$ \\
$\beta$-G1P & 0.77 & $6.5 \times 10^{2}$ \\
\hline
\end{tabular}

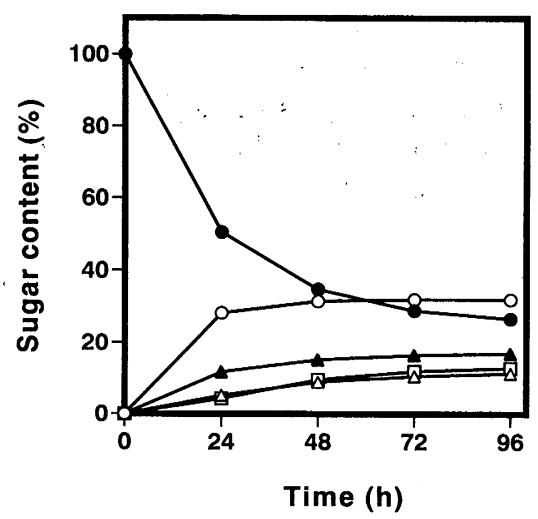

Fig. 3. Selaginose formation from trehalose by TPase and KPase.

The reaction mixture (final volume: $10 \mathrm{~mL}$ ) containing $5 \%(\mathrm{w} / \mathrm{w})$ trehalose, $20 \mathrm{~mm}$ acetate buffer ( $\mathrm{pH} 5.5)$, $2 \mathrm{~mm}$ sodium phosphate, $2 \mathrm{U}$ of purified TPase, and $2 \mathrm{U}$ of purified KPase was incubated at $60^{\circ} \mathrm{C}$ for $96 \mathrm{~h}$. Aliquots $(1 \mathrm{~mL})$ were withdrawn at various intervals, and the sugar composition in the reaction mixture was determined by HPLC. $\bullet$, trehalose; $\bigcirc$, selaginose; $\mathbf{\Lambda}$, glucose; $\triangle$, kojibiose; $\square$, others.

\section{Selaginose synthesis by purified TPase and} KPase.

In order to confirm the hypothetical mechanism described in our previous paper, ${ }^{7)}$ selaginose synthesis from trehalose was investigated using purified TPase and KPase. As shown in Fig 3, trehalose was decreased in content while selaginose and D-glucose were increased during the reaction. The selaginose content reached its maximum level, $32.1 \%$, at $96 \mathrm{~h}$.

\section{DISCUSSION}

In our previous paper, ${ }^{7)}$ we reported the formation of a non-reducing trisaccharide, selaginose, from trehalose by the cell-free extract of $T$. brockii. In addition, we proposed a hypothe- 
sis that two phosphorylases, TPase and KPase, were involved in the formation of selaginose as follows;

$$
\begin{aligned}
& \text { trehalose }+\mathrm{Pi} \underset{\text { TPase }}{\longrightarrow} \mathrm{D} \text {-glucose }+\beta-\mathrm{G} 1 \mathrm{P} \\
& \beta-\mathrm{G} 1 \mathrm{P}+\text { trehalose } \underset{\text { KPase }}{\longrightarrow} \text { selaginose }+\mathrm{Pi}
\end{aligned}
$$

In this study, we have succeeded in the purification and characterization of a novel phosphorylase, KPase, which catalyzed the second reaction described above. KPase catalyzed the reversible phosphorolysis of kojibiose. This is the first report on a phosphorylase that acts on the $\alpha-1,2$ glucosidic linkage.

The phosphorolytic activity of KPase was dependent on the concentration of $\mathrm{Pi}$ up to about $30 \mathrm{~mm}$. In the synthetic reaction of this enzyme, the liberation of $\mathrm{Pi}$ from glucose and $\beta$-G1P was measured at various intervals. A linear relationship : was obtained between released $\mathrm{Pi}$ and the reaction time (data not shown).

Purified KPase had the molecular weight of 83,000 by SDS-PAGE, and the native enzyme had the molecular weight of ' 500,000 'by gel filtlation. These results suggest, that the enzyme has a hexamer structure. KPase showed the highest activity at pH 5.5 and $65^{\circ} \mathrm{C}$, and was stable in a range from $\mathrm{pH} 5.5$ to 9.7 and at temperatures up to $65^{\circ} \mathrm{C}$. KPase activity was not inhibited in the presence of EDTA. It was considered that metals were not essential for the enzyme.

KPase specifically phosphorolyzed kojibiose, and was inactive on other disaccharides. - In contrast, KPase showed broad specificity for synthetic direction. Various monosaccharides and disaccharides having a glucosyl residue at the non-reducing end, were effective acceptors. Thus, it is considered that KPase is useful for the synthesis of saccharide having an $\alpha-1,2$ glucosidic linkage in its molecule.

Some studies relating to the synthesis of such oligosaccharides by $\alpha$-glucosidase ${ }^{6)}$ and CGTase $^{15)}$ through transglucosylation have been reported. For example, 2,4-di-O-( $\alpha$-D-glucopyranosyl) - $\alpha$-D-glucopyranose (centose) was synthesized by a transgluciosylation reaction of buckwheat $\alpha$-glucosidase ${ }^{6)}$ However, $O$ - $\alpha$-D-gluco- pyranosyl- $(1 \rightarrow 2)$ - $O$ - $\alpha$-D-glucopyranosyl- $(1 \rightarrow 4)$ $\alpha$-D-glucopyranose, a trisaccharide containing the $\alpha-1,2$ glucosidic linkage at the non-reducing end of maltose has not syntheized so far. Although various transfer products were formed from $\beta$-G1P and various acceptors, their structures remain unknown. Further work is needed to determine the structures of oligosaccharides prepared by KPase.

As shown in Fig. 3, selaginose was synthesized from trehalose by purified TPase and KPase. Therefore, it was confirmed that TPase and KPase were involved in the formation of selaginose by a cell-free extract of $T$. brockii.

We thank Ms. L. Keleher to her support in the preparation of this manuscript.

\section{REFERENCES}

1) K. Matsuda and K. Aso : Hakko Kogaku Zasshi, 31, 211-213 (1953) (in Japanese).

2) K. Aso and T. Watanabe: Nippon Nogei Kagaku Kaishi, 35, 1078-1082 (1961) (in Japanese).

3) T. Watanabe and K. Aso : Nature, 183, 1740 (1959).

4) A. Sato and K. Aso: Nature, 180, 984-985 (1957).

5) K. Matsuda, H. Watanabe, K. Fujimoto and K. Aso: Nature, 191, 278 (1961).

6) M. Takahashi, T. Shimomura and S. Chiba : Agric. Biol. Chem., 33, 1399-1410 (1969).

7) H. Chaen, T. Nishimoto, T. Yamamoto, T. Nakada, S. Fukuda, T. Sugimoto, M. Kurimoto and Y. Tsujisaka : J. Appl. Glycosci., 46, 129-134 (1999).

8) M. Kitaoka, H. Takahashi, K. Hara, H. Hashimoto, T. Sasaki and H. Taniguchi : Oyo Toshitsu Kagaku (J. Appl. Glycosci.), 41, 165-172 (1994).

9) Y. Tsumuraya, C. F. Brewer and E. J. Hehre: Arch. Biochem. Biophys., 281, 58-65 (1990).

10) M. Kitaoka, T. Sasaki and H. Taniguchi : Biosci. Biotechnol. Biochem., 56, 652-655 (1992).

11) M. Kitaoka, T. Sasaki and H..Taniguchi : Arch. Biochem. Biophys., 304, 508-514 (1993).

12) H. Kizawa, K. Miyagawa and Y. Sugiyama : Biosci. Biotechnol. Biochem., 59, 1908-1912 (1995).

13) J. B. Lloyd and W. J. Whelan : Anal. Biochem., 30, 467-470 (1964).

14) C. H. Fiske and A. Subbarow : J. Biol. Chem., 66, 375-400 (1925).

15) S. Kobayashi and N. Shibuya : Japan Kokai Tokkyo Koho 88216492 (Sep. 8, 1988).

(Received May 10, 1999; Accepted August 11, 1999) 
Thermoanaerobium brockii が産生する新規 ホスホリラーゼ, コージビオースホスホリラーゼ の精製とその諸性質

茶圓博人, 山本拓生, 西本友之 仲田哲也，福田恵温，杉本利行 栗本雅司，辻阪好夫

(侏)林原生物化学研究所 (700-0834 岡山市 天瀬南町 7-7)

好熱嫌気性菌 Thermoanaerobium brockii ATCC
35047 はコージビオースを可逆的に加リン酸分解し, $\beta$-グルコース 1-リン酸とグルコースを生成する新規 酵素, コージビオースホスホリラーゼを産生する。本 酵素を各種カラムクロマトグラフィーにより，菌体破 砕抽出液から電気泳動的に単一にまで精製した。本酵 素の分子量は 83,000, 等電点は 4.3-4.4であった。 本酵素の至適 $\mathrm{pH}$ は 5.5 , 至適温度は $65^{\circ} \mathrm{C}$ であった。 $\mathrm{pH}$ 安定性は 5.5-9.7, 温度安定性は $65^{\circ} \mathrm{C}$ までであっ た. 本酵素の活性は $\mathrm{Hg}^{2+}$ イオンと $\mathrm{Pb}^{2+}$ イオンで阻 害された。コージビオース, 無機リン酸, グルコー ス， $\beta$-グルコース1-リン酸に対する $K_{\mathrm{m}}$ 值はそれぞ れ $0.77 \mathrm{mM}, 0.85 \mathrm{~mm}, 3.52 \mathrm{mM}, 0.77 \mathrm{~mm}$ であった. 